Research article

\title{
USE OF MICROSATELLITES IN GENETIC DIVERSITY ASSESSMENT, PARENTAGE TESTING AND INDIVIDUAL IDENTIFICATION OF THE KANGAL SHEPHERD DOG
}

\author{
DIMITRIJEVIĆ Vladimir ${ }^{1 *}$, RISTANIĆ Marko², STANISIĆ Ljubodrag ${ }^{3}$, \\ DROBNJAK Darko ${ }^{4}$, UROSEVIĆ Milivoje ${ }^{4}$, OZKANAL Umit ${ }^{5}$, \\ STANIMIROVIĆ Zoran ${ }^{2}$
}

\begin{abstract}
${ }^{1}$ Department of Animal Breeding, Faculty of Veterinary Medicine, University of Belgrade, Serbia; ${ }^{2}$ Department of Biology, Faculty of Veterinary Medicine, University of Belgrade, Serbia; ${ }^{3}$ Department of Reproduction, Fertility and Artificial Insemination, Faculty of Veterinary Medicine, University of Belgrade, Serbia; ${ }^{4}$ Center for Preservation of Indigenous Breeds, Belgrade, Serbia; ${ }^{5}$ Faculty of Education, Eskisehir Osmangazi University, Eskisehir, Turkey.
\end{abstract}

(Received 02 October 2019, Accepted 08 April 2020)

\begin{abstract}
The Kangal Shepherd Dog is considered the most common dog breed of Turkish origin. This study investigated variations in ten autosomal microsatellite markers (PEZ01, PEZ03, PEZ05, PEZ06, PEZ08, PEZ12, PEZ20, FHC2010, FHC2054 and FHC2079) for the purposes of genetic diversity assessment of the Kangal breed. In addition, the use of markers was assessed in parentage testing and individual identification within the Kangal breed. The microsatellite markers were typed in 51 Kangal dogs. The total number of alleles in the study population was 69 . The mean number of alleles per locus was 6.9, and varied from four (FHC2079) to 12 (PEZ12). The polymorphic information content (PIC) ranged from 0.52 (FHC2079) to 0.87 (PEZ12), with the mean value for all loci of 0.717 . Power of exclusion (PE) in 10 microsatellites investigated varied between 0.143 (FHC2054) and 0.472 (PEZ08) per locus. In order to determine the efficiency of using microsatellites for individual identification in the Kangal breed, power of discrimination (PD) and matching probability (MP) were calculated for each microsatellite marker. The panel achieved high combined MP $\left(6.77 \times 10^{-10}\right)$ and high combined PD value of $99.99999 \%$. The obtained results may contribute to further recognition of the Kangal breed, and confirm that the investigated microsatellites enable a reliable parentage testing and individual identification of the breed.
\end{abstract}

Key words: allele frequency, canine microsatellites, genetic characterization, Kangal, parentage testing

\footnotetext{
*Corresponding author: e-mail: vanja@vet.bg.ac.rs
} 


\section{INTRODUCTION}

There are more than 400 breeds of domestic dogs (Canis familiaris L.), which vary considerably in morphology, physiology and behaviour. In contrast to such phenotypic variation across breeds, many dog breeds are characterized by reduced genetic diversity. Namely, over centuries of selective pressure exerted by humans, numerous canine breeds have been affected by genetic bottlenecks linked to inbreeding, variations in effective population size and frequent use of certain sires [1-8]. While various studies on genetic diversity across, as well as within different dog breeds, have been performed [9-11], data on Turkish native breeds are rather scarce.

The Kangal, the Akbash and the Kars Shepherd dog are native to Turkey and have been grouped into a single dog breed called the Anatolian shepherd dog [12]. However, findings reported by Erdogan et al. [13] and Yilmaz et al. [12] indicated that these three breeds are characterized by different genetic structures and that generalized grouping of the breeds is unfounded. The Kangal Shepherd Dog (KSD) was recognized by the Fédération Cynologique Internationale (FCI) as a native Turkish breed in 2018, and was classified in the FCI's Group 2, Section 2.2 under the Standard No 331 [14].

KSD is considered as the most common dog in Turkey, which is still widely used as a livestock guardian dog $[15,16]$. The breed standard had been first established by the Turkish Standard Institution in 1997, and soon after an initiative to further standardize and conserve the breed was launched [17]. A systematic cynological research was conducted to accomplish the goal of making a triage between many different shepherd dog breeds, and by following the cynological and zootechnical principles, selection and morphological measurements of the animals were undertaken [18]. As well as in any of the canine breeds, the implementation of measures for preserving genetic diversity in KSD and avoiding genetically carried diseases while keeping desirable phenotypic traits requires genetic structure data [19].

The aim of this study was to detect variations in 10 autosomal microsatellite markers for the purposes of genetic diversity assessment of the KSD breed, and to estimate the usefulness of the markers for both parentage testing and individual identification of the breed.

\section{MATERIALS AND METHODS}

\section{Sample collection}

For DNA analyses, buccal swab samples (Isohelix BEK-50 Single Step / Single Tube DNA Release Kit, Cell Projects Limited, United Kingdom) were collected from 51 dogs recorded in the birth book of the Turkish Kennel Association (KIF) as the KDS breed. All dogs included in the study population were unrelated by the first generation, older than 12 months at the time of sampling and localized in the area of town Sivas, central Anatolia (Figure 1). The sampled dogs were owned by individual owners and were working dogs used as livestock keepers. 


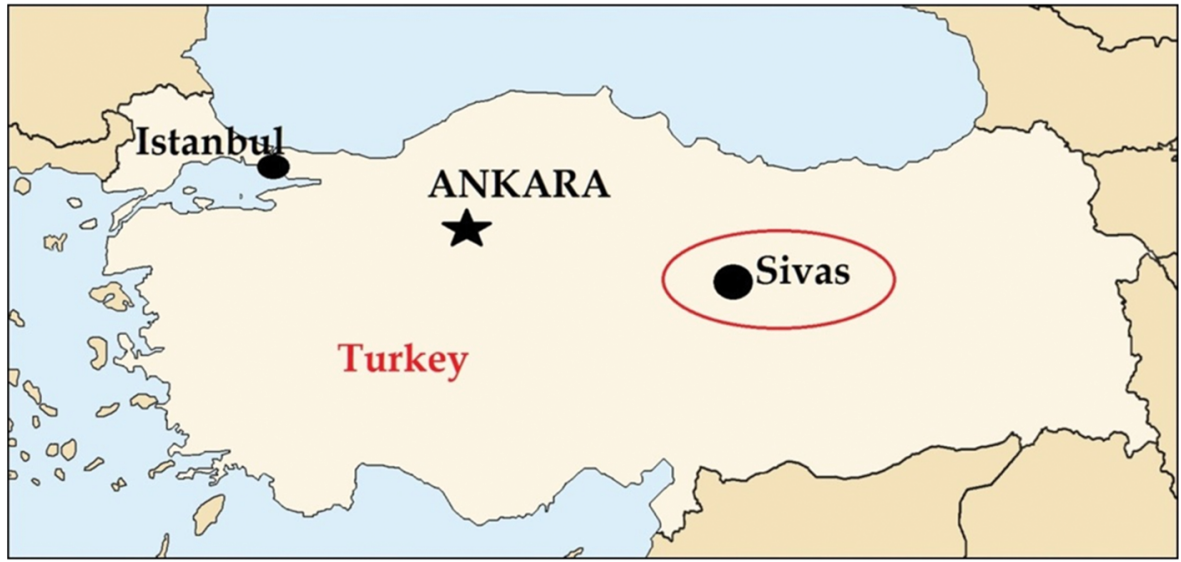

Figure 1. The area of Turkey from where the samples were collected

\section{Microsatellite analysis}

DNA was extracted according to the standard protocol for organic extraction of nucleic acids from eukaryotic cells [18]. DNA extracts were quantified using the BioPhotometer spectrophotometer system (Eppendorf, Hamburg, Germany). The genomic DNA concentrations ranged from $10 \mathrm{ng} / \mu \mathrm{l}$ up to $100 \mathrm{ng} / \mu \mathrm{l}$, which was in accordance with the manufacturer's recommendations for the StockMarks ${ }^{\circledR}$ for Dogs Canine Genotyping Kit (Applied Biosystems, Foster City, CA, USA). Microsatellites were amplified by PCR, as previously described [20]. In brief, 10 microsatellite markers (PEZ01, PEZ03, PEZ05, PEZ06, PEZ08, PEZ12, PEZ20, FHC2010, FHC2054 and FHC2079) were amplified by the StockMarks ${ }^{\circledR}$ for Dogs Canine Genotyping Kit (Applied Biosystems, PN 4346135) in accordance with the instructions provided by the manufacturer. The PCR amplification was carried out in the GeneAmp ${ }^{\circledR}$ PCR System 9700 (Applied Biosystems, Foster City, CA, USA), while the PCR products were separated by capillary electrophoresis in the ABI Prism ${ }^{\circledR} 310$ Genetic Analyzer (Applied Biosystems, Foster City, CA, USA).

\section{Data analysis}

The PCR products size was determined by Genotyper ${ }^{\circledR}$ and GeneScan ${ }^{\circledR}$ software packages (Applied Biosystems, Foster City, CA, USA). The genetic variability parameters and fixation indexes were calculated by the Arlequine ver. 3.5.2.2 software [21]. The following parameters were determined: total number of alleles, mean number of alleles per locus, observed (HO) and expected (HE) heterozygosity, deviations from the Hardy-Weinberg equilibrium (HWE), linkage disequilibrium between pairs of loci and polymorphic information content (PIC) for all alleles. Power of exclusion (PE) and power of discrimination (PD) were calculated for each microsatellite loci, while combined PE and combined PD were calculated for the whole set of markers. PE and 
PD were determined by using PowerStats ver. 1.2 freeware (Promega Corporation, USA). P value of 0.005 was considered significant.

The Ethics Commission of the Faculty of Veterinary Medicine, University of Belgrade, waived the need for ethics approval and the need to obtain consent for the collection, analysis and publication of the data for this non-interventional study which used a noninvasive sampling technique.

\section{RESULTS}

The total number of alleles (Figure 2) in the studied population was 69. The number of alleles per locus ranged from 4 (for FHC2079) to 12 (PEZ12) and was 6.9 on average.

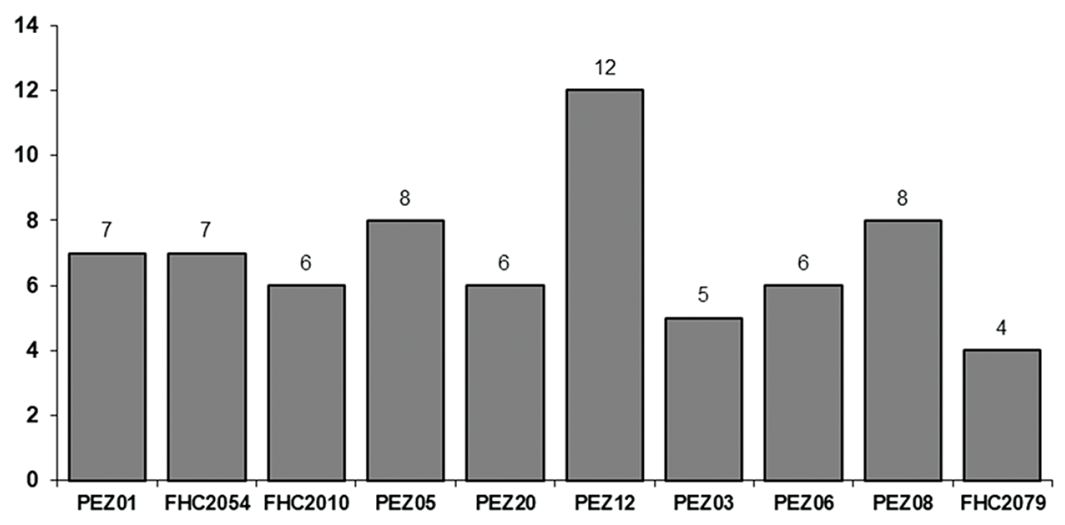

Figure 2. Number of alleles per microsatellite in 10 investigated loci in populations of the Kangal breed

The highest number of alleles was established for the locus PEZ12 (Figure 2). Out of the 12 alleles recognized, the allele 4 had the highest frequency in the population tested, namely $20 \%$, while the frequencies of other identified alleles were rather low (Table 1). The highest frequency of a single allele in all markers analysed was found for locus PEZ06 (allele 6).

The mean values of $\mathrm{HO}$ and $\mathrm{HE}$ were 0.55 and 0.77 , respectively (Table 2$)$. HO ranged from 0.44 (FHC2054) to 0.72 (PEZ08), whereas HE varied between 0.60 (FHC2079) and 0.89 (PEZ12).

Tests for deviation from HWE showed a significant $(\mathrm{P}<0.005)$ difference between the observed and the expected genotype frequencies at two loci only - FHC2054 and PEZ12.

The PIC values ranged from 0.52 (FHC2079) to 0.87 (PEZ12), being 0.717 on average for all loci (Figure 3). As far as paternity testing is concerned, power of exclusion (PE) in 10 investigated microsatellites in populations of the KSD breed ranged from 0.143 
(FHC2054) to 0.472 (PEZ08) per locus (Figure 4). The combined PE calculated for the whole set of markers was 0.9999 .

Table 1. Number of alleles and allele frequencies in investigated microsatellites in the Kangal breed

\begin{tabular}{|c|c|c|c|c|c|}
\hline Locus & Allele* & Frequency & Locus & Allele* & Frequency \\
\hline \multirow{7}{*}{ PEZ01 } & 1 & 0.023 & \multirow{13}{*}{ PEZ12 } & 2 & 0.067 \\
\hline & 2 & 0.291 & & 3 & 0.133 \\
\hline & 3 & 0.221 & & 4 & 0.200 \\
\hline & 4 & 0.209 & & 5 & 0.033 \\
\hline & 5 & 0.221 & & 6 & 0.083 \\
\hline & 6 & 0.023 & & 7 & 0.117 \\
\hline & 7 & 0.012 & & 8 & 0.050 \\
\hline \multirow{9}{*}{ FHC2054 } & & & & 11 & 0.017 \\
\hline & 1 & 0.111 & & 12 & 0.150 \\
\hline & 2 & 0.056 & & 13 & 0.050 \\
\hline & 3 & 0.167 & & 14 & 0.017 \\
\hline & 5 & 0.111 & & 16 & 0.083 \\
\hline & 6 & 0.278 & & & \\
\hline & 7 & 0.167 & \multirow{5}{*}{ PEZ03 } & 1 & 0.083 \\
\hline & 8 & 0.111 & & 2 & 0.167 \\
\hline & & & & 6 & 0.500 \\
\hline \multirow{7}{*}{ FHC2010 } & 2 & 0.056 & & 8 & 0.167 \\
\hline & 3 & 0.444 & & 10 & 0.083 \\
\hline & 4 & 0.167 & \multirow{8}{*}{ PEZ06 } & & \\
\hline & 5 & 0.278 & & 1 & 0.200 \\
\hline & 11 & 0.028 & & 2 & 0.167 \\
\hline & 12 & 0.028 & & 3 & 0.100 \\
\hline & & & & 4 & 0.233 \\
\hline \multirow{9}{*}{ PEZ05 } & 1 & 0.011 & & 5 & 0.200 \\
\hline & 2 & 0.196 & & 6 & 0.100 \\
\hline & 3 & 0.207 & & & \\
\hline & 4 & 0.489 & \multirow{8}{*}{ PEZ08 } & 1 & 0.080 \\
\hline & 5 & 0.065 & & 2 & 0.114 \\
\hline & 6 & 0.011 & & 3 & 0.159 \\
\hline & 7 & 0.011 & & 4 & 0.182 \\
\hline & 8 & 0.011 & & 5 & 0.318 \\
\hline & & & & 6 & 0.057 \\
\hline \multirow{7}{*}{ PEZ20 } & 3 & 0.245 & & 7 & 0.057 \\
\hline & 4 & 0.266 & & 8 & 0.034 \\
\hline & 5 & 0.255 & \multirow{5}{*}{ FHC2079 } & & \\
\hline & 6 & 0.170 & & 3 & 0.500 \\
\hline & 7 & 0.043 & & 4 & 0.380 \\
\hline & 8 & 0.021 & & 5 & 0.087 \\
\hline & & & & 8 & 0.033 \\
\hline
\end{tabular}

*Nomenclature of alleles was determined in accordance with internal ladder. 
Table 2. Hardy-Weinberg equilibrium (HWE) in the investigated population of the Kangal breed

\begin{tabular}{lcccc}
\hline Locus & $\mathbf{H}_{\mathbf{o}}$ & $\mathbf{H}_{\mathbf{E}}$ & $\mathbf{p}$ & SD \\
\hline PEZ01 & 0.58140 & 0.78194 & 0.06224 & 0.00024 \\
\hline FHC2054 & 0.44444 & 0.87582 & 0.00046 & 0.00002 \\
FHC2010 & 0.50000 & 0.71270 & 0.02729 & 0.00016 \\
\hline PEZ05 & 0.58696 & 0.68251 & 0.01285 & 0.00011 \\
PEZ20 & 0.62500 & 0.78004 & 0.08515 & 0.00025 \\
PEZ12 & 0.51613 & 0.89635 & 0.00000 & 0.00000 \\
PEZ03 & 0.50000 & 0.74242 & 0.16955 & 0.00042 \\
PEZ06 & 0.53333 & 0.84598 & 0.11147 & 0.00026 \\
PEZ08 & 0.72727 & 0.82288 & 0.80294 & 0.00042 \\
FHC2079 & 0.50000 & 0.60320 & 0.06745 & 0.00028 \\
Mean value & 0.55145 & 0.77439 & & \\
\hline
\end{tabular}

$\mathrm{HO}$ - observed heterozigosity; HE - expected heterozigosity, $\mathrm{p}$ - p value, SD - standard deviation.

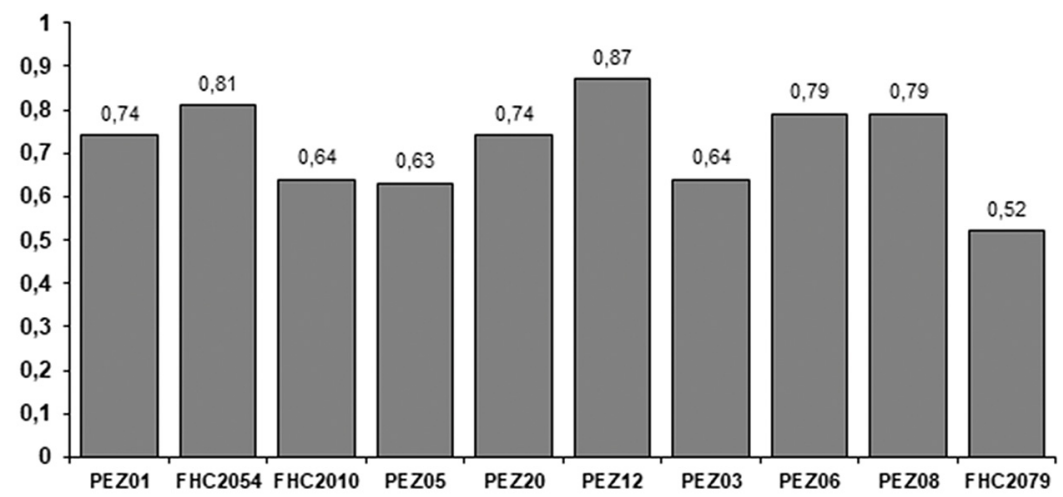

Figure 3. Polymorphic Information Content (PIC) in investigated microsatellites

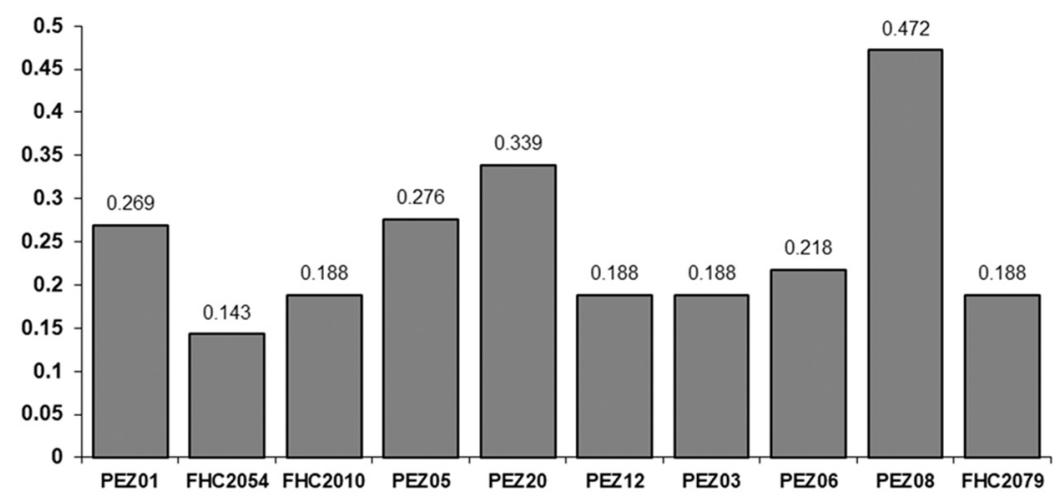

Figure 4. Power of exclusion (PE) in 10 investigated microsatellites in populations of the Kangal breed 
The calculated power of discrimination (PD) and matching probability (MP) for each microsatellite marker (Figure 5) achieved high combined MP $\left(6.77 \times 10^{-10}\right)$ and high combined PD value of $99.99999 \%$.

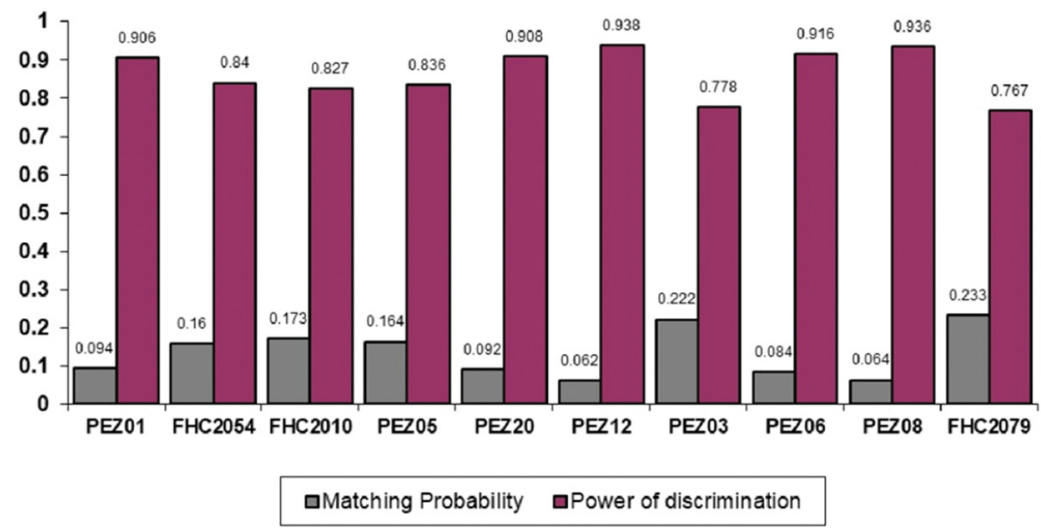

Figure 5. Power of discrimination (PD) and matching probability (MP) in 10 investigated microsatellites in populations of the Kangal breed

\section{DISCUSSION}

The genetic diversity parameters based on microsatellite markers established in the present study indicate high level of genetic diversity within the study sample of KSD. In comparison with the results of some earlier research, the number of alleles we found in the KSD breed was rather high: 4-12, and 6.9 on average. DeNise et al. [22], assessed the same set of microsatellite loci in 108 different dog breeds, and found that the mean number of alleles per breed was between 2.9 (Skye Terrier) and 8.4 (Australian Shepherd). Völkel [23] examined the polymorphisms of the same set of microsatellite markers in $14 \mathrm{dog}$ breeds with the average number of alleles per breed ranging from 3.6 (Doberman Pinscher) to 6.7 (wire-haired Dachshund). In the study by Truksa et al. [24] the average number of alleles per marker in the Caucasian Shepherd was 5.2, and in the Czech Terrier 2.5. Forensic investigation of canine hair samples with the same STRs loci [25] displayed polymorphism in all markers analysed, where the number of alleles per locus varied between 5 (FHC2010) and 20 (PEZ3). Finally, Erdogan et al. [13] investigated the genetic variability among native dog breeds in Turkey, including 30 specimens of the KSD, using 20 polymorphic loci (17 microsatellites and 3 proteins) and found high numbers of alleles (10.85 on average), which ranged between 3 (FHC2079) and 26 (FH2247).

The mean HO (Table 2) for the KSD breed was also high, and had similar values to those reported by Völkel [23] and DeNise et al. [22], who established the HO values of 0.56 and 0.57 , respectively, calculated from data for all breeds. However, previous investigation focused on KSD [13] revealed a higher value (0.766) of HO, 
but similar values of $\mathrm{HE}$ (0.763). The relatively high value of $\mathrm{HO}$ in the KSD breed is comparable to that in breeds classified as "old" by DeNise et al. [22]. Criteria for this breed classification into ancient and modern Eurasian origin were based upon the comprehensive phylogenetic analysis of 85 domestic dog breeds by Parker et al. [18]. The HO values for locus PEZ08 as reported by DeNise et al. [22] ranged from 0.57 (Siberian husky) to 0.82 (Tibetan terrier). The only breed in this group which had a relatively low $\mathrm{HO}$ value for PEZ08 - 0.18 - was the Afghan hound. Furthermore, in comparison to $\mathrm{HO}$ values of dog breeds classified in FCI group II [22], those for PEZ08 were significantly lower in most breeds, with the exception of the Miniature Schnauzer, whose $\mathrm{HO}$ was 0.7 . The rest of the group showed HO in this locus to range from 0.5 to 0.6. Finally, the $\mathrm{HO}$ value obtained for PEZ08 in our research was higher than, or in range with those in other shepherd dog breeds tested by DeNise et al. [22], with the exception of the Belgian shepherd (0.77) in which it was almost the same.

In the KSD population that we have tested, 8 out of 10 analysed microsatellite loci were in a state of HWE. The significant deviation $(p=0.005)$ from HWE was observed only for two loci: FHC2054 and PEZ12 (Table 2). Seven alleles were found for FHC2054, with allele 6 showing the highest homozygosity, while PEZ12 was identified as the locus with the most alleles (12). The relatively high frequencies of allele 6 (FHC2054) and allele 4 (PEZ12) in the population of the KSD breed, account for the disequilibrium found at these loci. A possible explanation for this disequilibrium may be a quantitative trait linked to these markers under selection pressure, although this is yet to be confirmed by further analysis.

In our KSD population, the average PIC for all loci - 0.717 - was higher than the values established in previous studies [22,26]. All analysed loci showed PICs $\geq 0.5$, which indicates a high informativeness gained from the genetic markers [26]. The lowest PIC value was observed for the locus FHC2079, which is consistent with its low heterozygosity. The KSD was traditionally bred as a working dog, but has gained popularity as a companion and, consequently, as a show dog. In addition, the discrepancies in findings such as for the observed heterozygosity of the PEZ08 marker between KSD and other dogs of the FCI II group could result from different breeding factors that influence the dog genome.

The high value of combined PE 0.9999 observed in the population of the KSD breed corresponds to the combined PE reported by previous studies that used identical panel of microsatellite markers in other dog breeds: 0.9955 [27] and 0.9999 for the Dachshund [28]; 0.9904 for the German Shepherd, 0.9942 for the Rottweiler, 0.9998 for the Schnauzer [28]; and 0.9989 in the population of the Yugoslavian Shepherd Dog [20]. Moreover, the combined PE value established in this study corresponds to the one recommended for accurate parentage testing in dogs [29]. In addition, the high combined MP $\left(6.77 \times 10^{-10}\right)$ and PD value $(99.99999 \%)$ obtained for the investigated KSD breed indicate the suitability of used microsatellite markers for paternity testing and individual identification in this breed. 
In conclusion, our results indicate that the KSD breed retains high level of genetic diversity, especially when compared with breeds that are under more intensive breeding programmes. One of the presumed reasons for exhibited diversity could be occasional hybridization of the KSD with European wolves during North Eurasian human migration [15]. The data resulting from the current research can be used to support the KSD breed recognition, and contribute to development of breeding programme adjusted to the specific characteristics of the KSD as a valuable genetic resource of the Eurasian region. Furthermore, the microsatellites studied can be used for analyses of parentage testing and individual identification of the KSD breed.

\section{Acknowledgements}

The authors are grateful to the Ministry of Education, Science and Technological Development of the Republic of Serbia for funding this work (Project No. III46002).

\section{Authors' contributions}

$\mathrm{NK}$ designed investigation, interpreted the results and wrote the paper. KP performed investigation and co-wrote the paper. VM and ZB performed the statistical anaylsis, analyzed the data and reviewed the manuscript. TR, ŽD, TR and JLj helped performed analysis and co-wrote the paper. All authors read and approved the final manuscript.

\section{Declaration of conflicting interests}

The author(s) declared no potential conflicts of interest with respect to the research, authorship, and/or publication of this article.

\section{REFERENCES}

1. Mellersh C: Give a dog a genome. Vet J 2008, 178:46-52.

2. Galibert F, Quignon P, Hitte C, André C: Toward understanding dog evolutionary and domestication history. C R Biol 2011, 334:190-196.

3. Pedersen N, Liu H, Theilen G, Sacks B: The effects of dog breed development on genetic diversity and the relative influences of performance and conformation breeding. J Anim Breed Genet 2013, 130:236-248.

4. Shannon LM, Boyko RH, Castelhano M, Corey E, Hayward JJ, McLean C, Whitea ME, Abi Saide M, Anitaf BA, Bondjengog NI, Caleroh J, Galovi A, Hedimbij M, Imamk B, Khalapl R, Lallym D, Mastan A, Oliveiraa KC, Pérezo L, Randallp J, Tamq NM, TrujilloCornejoo FJ, Valerianoh C, Sutterr NB, Todhunterc RJ, Bustamantes CD, Boykoa AR: Genetic structure in village dogs reveals a Central Asian domestication origin. Proc Natl Acad Sci U S A 2015, 112:13639-13644.

5. Freedman AH, Schweizer RM, Ortega-Del Vecchyo D, Han E, Davis BW, Gronau I, Silva PM, Galaverni M, Fan Z, Marx P, Lorente-Galdos B, Ramirez O, Hormozdiari F, Alkan C, Vilà C, Squire K, Geffen E, Kusak J, Boyko AR, Parker HG, Lee C, Tadigotla V, Siepel 
A, Bustamante CD, Harkins TT, Nelson SF, Marques-Bonet T, Ostrander EA, Wayne RK, Novembre J: Demographically-based evaluation of genomic regions under selection in domestic dogs. PLoS Genet 2016, 12:e1005851.

6. Wang GD, Zhai W, Yang HC, Wang L, Zhong L, Liu YH, Fan RX, Yin TT, Zhu CL, Poyarkov AD, Irwin DM, Hytönen MK, Lohi H, Wu CI, Savolainen P, Zhang YP: Out of southern East Asia: the natural history of domestic dogs across the world. Cell Res 2016, 26:21-33.

7. Ostrander EA, Wayne RK, Freedman AH, Davis BW: Demographic history, selection and functional diversity of the canine genome. Nature Rev Genet 2017, 18: 705-720.

8. Parker HG, Dreger DL, Rimbault M, DavisBW, Mullen AB, Carpintero-Ramirez G, Ostrander EA: Genomic analyses reveal the influence of geographic origin, migration, and hybridization on modern dog breed development. Cell Rep 2017, 19:697-708.

9. Bigi D, Marelli SP, Randi E, Polli M: Genetic characterization of four native Italian shepherd dog breeds and analysis of their relationship to cosmopolitan dog breeds using microsatellite markers. Animal 2015, 9:1921-1928.

10. Dreger DL, Rimbault M, Davis BW, Bhatnagar A, Parker HG, Ostrander EA: Wholegenome sequence, SNP chips and pedigree structure: building demographic profiles in domestic dog breeds to optimize genetic-trait mapping. Dis Model Mech 2016, 9:14451460.

11. Mastrangelo S, Biscarini F, Tolone M, Auzino B, Ragatzu M, Spaterna A, Ciampolini R: Genomic characterization of the Braque Français type Pyrénées dog and relationship with other breeds. PloS One 2018, 13:p.e0208548.

12. Yılmaz O, Ertürk YE, Çoşkun F, Ertuğrul M: Using livestock guardian dogs in Balkans. Agricult Forest 2015, 61:161-173.

13. Erdoğan M, Tepeli C, Brenig B, Akbulut M, Uğuz C, Savolainen P, Özbeyaz C: Genetic variability among native dog breeds in Turkey. Turk J Biol 2013, 37: 176-183.

14. FCI-Standard No 331: Kangal Çoban Köpeği (Kangal Shepherd Dog). [http://www.fci.be/ Nomenclature/Standards/331g02-en.pdf]

15. Koban E, Saraç ÇG, Açan SC, Savolainen P, Togan İ: Genetic relationship between Kangal, Akbash and other dog populations. Discrete Appl Math 2009, 157:2335-2340.

16. Yilmaz O, Ertugrul M: Determination of Kars Shepherd Dog Raised in Turkey. CJPAS 2012, p.2127.

17. Cilek S, Kavak G: Some morphological characteristics of kangal shepherd dogs (Karabas) raised at villages by farmers in Kirikkale province. Asian J Anim Vet Adv 2012, 7:403-411.

18. Parker HG: Genomic analyses of modern dog breeds. Mamm Genome 2012, 23: 19-27.

19. Budowle B, Garofano P, Hellman A, Ketchum M, Kanthaswamy S, Parson W, Van Haeringen W, Fain S, Broad T: Recommendations for animal DNA forensic and identity testing. Int J Legal Med 2005, 119:295-302.

20. Dimitrijevic V, Stevanovic J, Savic M, Petrujkic B, Simeunovic P, Milosevic I, Stanimirovic Z: Validation of 10 Microsatellite Loci for Their use in Parentage Verification and Individual Identification in the Yugoslavian Shepherd Dog Sharplanina. Ann Anim Sci 2013, 13:715722.

21. Excoffier L, Lischer HE: Arlequin suite ver 3.5: a new series of programs to perform population genetics analyses under Linux and Windows. Mol Ecol Resour 2010, 10:564567. 
22. DeNise S, Johnston E, Halverson J, Marshall K, Rosenfeld D, McKenna S, Sharp T, Edwards J: Power of exclusion for parentage verification and probability of match for identity in American kennel club breeds using 17 canine microsatellite markers. Anim Genet 2004, 35:14-17.

23. Völkel I: Untersuchungen zur molekulargenetischen Rassendifferenzierung bei Canis familiaris. PhD Thesis. Humboldt University of Berlin, 1-154, 2005.

24. Truksa M, Urban T, Putnová L: Analysis of genetic diversity in Caucasian Shepherd Dog and Czech Terrier dog breeds using microsatellite loci. Biotech 2008, 1:409-411.

25. Ganço L, Carvalho M, Serra A, Balsa F, Bento AM, Anjos MJ, Xufre A, Côrte-Real F: Genetic diversity analysis of 10 STR's loci used for forensic identification in canine hair samples. Forensic Sci Int Genet Suppl Ser 2009, 2:288-289.

26. Lüpke L, Distl O: Microsatellite marker analysis of the genetic variability in Hanoverian Hounds. J Anim Breed Genet 2005, 122:131-139.

27. Přibáňová M, Horak P, Schröffelová D, Urban T, Bechyňová R, Musilova L: Analysis of genetic variability in the Czech Dachshund population using microsatellite markers. J Anim Breed Genet 2009, 126:311-318.

28. Zenke P, Egyed B, Zöldág L, Pádár Z: Population genetic study in Hungarian canine populations using forensically informative STR loci. Forensic Sci Int Genet 2011, 5:pp. e31-e36.

29. Halverson JL: Microsatellite polymorphism in dog breeds-the AKC parent club study. In Proc. 27th ISAG Conference of Animal Genetics 2000, pp 19.

\title{
UPOTREBA MIKROSATELITA U PROCENI GENETIČKOG DIVERZITETA, KONTROLI RODITELJSTVA I INDIVIDUALNOJ IDENTIFIKACIJI PASA RASE KANGAL
}

\author{
DIMITRIJEVIĆ Vladimir, RISTANIĆ Marko, STANISIĆ Ljubodrag, DROBNJAK \\ Darko, UROSEVIĆ Milivoje, OZKANAL Umit, STANIMIROVIĆ Zoran
}

Kangal rasa pasa se smatra jednom od najčešćih rasa turskog porekla. Ova studija je istraživala varijacije deset autozomalnih mikrosatelitskih markera (PEZ01, PEZ03, PEZ05, PEZ06, PEZ08, PEZ12, PEZ20, FHC2010, FHC2054 i FHC2079) u svrhu određivanja genetičkog diverziteta pasa rase kangal. Pored toga, izvršena je procena mogućnosti primene ovih markera u individualnoj identifikaciji i u kontroli roditeljstva pasa rase kangal. Izvršena je tipizacija navedenih mikrosatelitskih markera kod 51 jedinke kangal rase. Ukupan broj alela u ispitivanoj populaciji iznosio je 69. Prosečan broj alela po lokusu iznosio je 6,9 sa varijacijama od četiri (FHC2079) do 12 (PEZ12). Polimorfizam (PIC) je varirao od 0,52 (FHC2079) do 0,87 (PEZ12), sa srednjom vrednošću od 0,717 za sve lokuse. Verovatnoća isključenja (PE) 10 mikrosatelitskih markera varirala je između 0,143 (FHC2054) i 0,472 (PEZ08) po lokusu. U cilju utvrđivanja efikasnosti u svrhu individualne identifikacije pasa rase kangal, odredivana je moć diskriminacije (PD) kao i verovatnoća podudaranja (MP) za svaki od ispitivanih 
markera. Ispitivani panel postigao je visoke vrednosti kako kombinovane MP $(6,77 \times$ $10^{-10}$ ) tako i kombinovane PD od 99,99999\%. Dobijeni rezultati predstavljaju doprinos genetičkoj karakterizaciji rase kangal i pokazuju da je ispitivani panel mikrosatelitskih markera pouzdan u kontroli spornih rodbinskih odnosa i u individualnoj identifikaciji pasa ove rase. 